\title{
Fator de Impacto 2013
}

\section{Caros leitores}

Recentemente foi divulgado o Fator de Impacto referente ao ano de 2013 (Thomson Reuters, Journal Citation Reports® 2014). Foi com satisfação que verificamos que a revista Polímeros passou de 0.493 (2012) para 0.632, ou seja, um aumento de 28,2\%. Certamente, pretende-se atingir gradativamente níveis superiores ao presente.

Nossa meta é avançar de forma continuada no sentido de divulgar a revista internacionalmente, considerando que nacionalmente este periódico é amplamente conhecido da comunidade que atua na área de polímeros. No mês de julho do presente ano, o maior percentual de acesso ao periódico, oriundo de outros países, correspondeu aos Estados Unidos, seguido do bloco europeu constituído por Portugal, Alemanha, Espanha, França, Itália e, na sequência, China.

Como parte das ações necessárias para atingir a meta pretendida, a revista se encontra atualmente em processo de revisão, no que se refere ao formato do processo de submissão. Adicionalmente, insistimos novamente em assunto já tratado em editoriais passados, ou seja, incentivamos fortemente os pesquisadores que pretendam submeter manuscritos para Polímeros: Ciência e Tecnologia a priorizarem a submissão daqueles redigidos em inglês, o que aumentará de forma significativa a visibilidade da pesquisa que resultou no artigo publicado, além de em muito ampliar o público internacional que acessa este periódico.

Abraços

Elisabete Frollini

\section{Mensagem da Diretoria de Inovação e Tecnologia e Diretoria de Comissóes Técnicas da ABPol}

As Diretorias de Inovação/Tecnologia e Diretoria de Comissões Técnicas informam que o Ciclo de Programas Interlaboratoriais (PIs) 2014 teve encerramento de inscrições em 21/07/2014. Foram lançados quatro PIs compreendendo os de Índice de Fluidez (MFI), Espectroscopia no Infravermelho (FTIR), Termogravimetria (TG) e Teor de Cinzas. Destaca-se o pioneirismo da ABPol no lançamento de dois novos PIs, que são os de Termogravimetria e Perda ao Fogo, assim como já ocorreu no passado com os PIs de Espectroscopia no Infravermelho e Calorimetria Exploratória de Varredura (DSC).

Como contribuição fundamental, estes programas de proficiência apoiam a avaliação da qualidade dos ensaios realizados por laboratórios da indústria, instituições de pesquisa e agências reguladoras, dentre outros. Os resultados individuais de cada laboratório/equipamento são totalmente sigilosos, servindo como indicativo do desempenho de um determinado equipamento perante os demais. Outra vantagem na participação de PIs é que para determinadas análises, as amostras utilizadas nos PIs poderão servir como referência para averiguação do equipamento ao longo de um período.

Para este Ciclo de PIs tivemos a satisfação de encerrar a fase de inscrições com a participação entre 16 a 20 equipamentos para cada um dos PIs, totalizando cerca de 70 equipamentos que serão avaliados comparativamente. As Diretorias de Inovação/Tecnologia e Diretoria de Comissões Técnicas agradecem a participação de todas as empresas e instituições participantes de mais este Ciclo de PIs. 